\title{
Situating Iraq in Oxford: Reflections on Identity, Place, and Justice
}

\author{
Mariam Hassoun \\ University of Oxford, United Kingdom
}

I write this essay on a gloomy day, seated in the corner of the cafe at Blackwell's bookshop in Oxford, England. Towering over me in this town are the infirm feet of Cecil Rhodes at Oriel College and the 'Emperor heads' of the Sheldonian theatre. The city's architecture is a constant reminder of this place's colonial history, which was built to exploit people like me."

One hundred and one year ago, women could not pursue degrees from this University. Even today, there are only three Iraqis enrolled as students (University of Oxford, 2021). I am one of the 1,258 graduate students from the United States of America. The greatest number of international graduate students at Oxford come from the United States, making up approximately $10 \%$ of the graduate student population. What if my parents had not escaped Saddam Hussein's Iraq for Yemen, later making their way to New Zealand where I was born, and eventually raising my brother and me in the United States-would I be at Oxford? Would I be one of the three?

As a master's student and a woman of Iraqi heritage, researching Iraqi education at the University, I remind myself that there is great power and responsibility in occupying space in this site of sacred knowledge. In this essay, I explore Eve Tuck's theorization of damage-centered research and Scheper-Hughes' activist anthropology and reflect on its relevance to my research. I seek to blur the lines between researcher and researched, highlighting how education can be used as a powerful tool to amplify untold stories.

For my dissertation, I conducted semi-structured interviews with a diverse group of internally displaced persons (IDPs) in the Iraqi dialect of Arabic; I sought to understand how they navigated educational access for their children. In pursuing this research, I interviewed Farida, ${ }^{1}$ whose powerful call for her story to reach the world led me to think critically about how and to whom I need to share my research.

In 2014, Farida woke up to pounding on her door. Outside her intergenerational family home in Sinjar, Daesh insurgents arrived to kidnap or murder her family; they ran to Mount Sinjar to escape the Yazidi genocide. Seven years later, she told me her story in a rented Duhok apartment, not far from the IDP camp she initially fled to, seeing no possibility of returning "home."

In "Suspending Damage: A Letter to Communities," Eve Tuck (2009) discusses "damagecentered research," which in essence aims to document people's pain and suffering and identifies the long-term negative impacts of this type of research on our conceptualization of communities. Our ideas and assumptions about a community carry real-world consequences. Moreover, real human suffering is often "aestheticized" and "turned into theatre" on the journal's stage (Scheper-Hughes, 1995). As someone with a family living

\footnotetext{
${ }^{1}$ To protect the interviewee's privacy, I use the name Farida in this essay.
} 
in Iraq, I understand these stories and challenges as tangible, not theoretical, and thus view the exploitation of human pain as personal.

Tuck's letter calls on us to question our epistemological biases - what types of stories do we share about displaced people? Most often, we share and write about their stories of despair. Farida defied much of these stereotypical framings. She spoke with radiance through the phone. She is living a meaningful life and working with the purpose of making life better for her displaced community, especially women. While living in the Duhok camp, she began to work with NGOs to support humanitarian aid provisions. She eventually started her own non-formal education program for women aged 15-45 years old to provide literacy and numeracy classes. Most of the women had never entered a school building, but Farida proposed educational spaces as a place in which these women could have the opportunity to heal through community, support, and skill-building.

As a young girl growing up in Sinjar, she had to stop schooling in middle school due to her family's circumstances. While she could not achieve her childhood dream of becoming a doctor, she, as an adult, is determined to instill hope for a better future in the hearts of her community:

"If I could say anything to the world, and I know there are people who have it worse than me, so maybe I am in a better position than so many. And the life I've seen goes so much further than just me. I have a duty to manage all of this. There are so many solutions to our problems. We have hope our lives will get better. I want my voice to reach the world. I think of it from the lens of being a woman. We were persecuted against greatly. I love everyone who can help us. We need someone to lift our voices up. We love peace. We don't hurt people. We are all humans, there's no difference between us. So many people have helped me from different places. Yazidis, Christians, Muslims. I want people to know that there are good of all of us." (Farida, personal communication, February 20, 2021).

As she was speaking on the phone, I could not help but think that Farida and I, although obviously different with respect to our geographical luck, were the same in many ways. I, too, work to identify practical solutions and raise awareness by uplifting voices alongside a deep-rooted belief in our shared goodness and humanity.

As I conversed with interviewees, I grappled with guilt as I collected and recorded hardship, including near starvation, chronic illness, poverty. These circumstances are both intimately close and far removed from my reality. I kept thinking: this could have been me and my family, so what can I do about it?

Iraqis are painted dominantly as a monolithic, victimized mass in need of Western rescuing. Maintaining this framing not only reinforces the dichotomy of the rescuer (via NGOs and Western governments) and rescued (IDPs) but can quickly cause problems for displaced persons and refugees in that they are then perceived and treated as societal burdens (Parekh, 2020; Ghorashi, 2005).

At Oxford, I was surprised to find that maybe I was framed as someone inherently traumatized and in desperate need of saving to achieve my research aims. When I sought vicarious trauma counseling through the University in order to cope with the emotions arising from the interviews, I was told that my unrealistic motivations to create positive change were rooted in a desire to explore family trauma passed down to me by my mother (and even those generations before her); it would be in my best interest to turn off my emotional faucet in order to be a better tool for research. How could my sensitivity to 
human pain have been so misunderstood to be seen as so corruptive to my work, if not for misinformed, preconceived notions of what it means to be Iraqi?

In "The Primacy of the Ethical: Propositions for a Militant Anthropology", Nancy Scheper-Hughes (1995) established the 'militant' approach to anthropology, which is politically and morally engaged, self-critical, and interventionist. Decolonization and critical methodologies "are not a metaphor" but are rather radically directed towards seeking justice and repatriation for indigenous communities facing the violent realities of settler colonialism and imperialism (Tuck \& Yang, 2012). To me, being Iraqi means 1) raising my voice to tell a different story by "identif[ying] ills in spirit of solidarity" and 2) consciously using my privilege to collaboratively put social change in action (ScheperHughes, 1995, p 419). In short, this lies within the following framework: think critically, speak publicly, and act with and for communities in need.

Scheper-Hughes calls researchers to surrender to the reality that there is no such thing as objective or apolitical human behavior, nor can social science research regarding real-life problems be siloed in the realm of theoretical abstraction. As a first-generation immigrant to the United States, I have never known an apolitical life-my very existence in the post9/11 United States is inherently political, just as it is at the University of Oxford.

I am committed to building some sort of response to issues in educational navigation (such as the need for after-school support, lack of material resources, and vouchers to cover additional costs of education i.e., transportation) in collaboration with displaced Iraqis. I have begun having conversations with people I met throughout the research process to get these projects started sustainably. In the short term, however, I believe my action lies in highlighting indigenous voices and advocating for education as a human right in the Middle East, specifically Iraq.

I created semi-fictionalized accounts of the IDP interviews I conducted in my research to publish on my personal Twitter in plain English. I believe it is my duty as a researcher to make unheard stories heard. Tuck and Scheper-Hughes' papers influenced my approach to writing and researching in that they reminded me of 1) the care and nuance necessary in framing IDP stories beyond victimization and 2) my duty to act in earnest.

My commitment lies not only within myself, but also the people and topics I work with through research. A crucial part of my work as an academic and activist-but more importantly as a human being-is creating space for critical conversations. Acknowledging the institutional barriers to academic activism embedded within the University, my research creatively subverts oppressive epistemological systems through decolonized methodologies and values. My research aims to center the voices of Iraqi IDPs and emphasize their own agency to spark a conversation for displaced Iraqis and academics alike leading to tangible action. I call for a people-centered ethos to research in which we all, researcher and researched, can nurture our humanity.

Mariam Hassoun completed her MSc in Education (Comparative and International Education) at the University of Oxford in September 2021. She is interested in how education can be used to reconstruct systems, countries, and persons impacted by conflict and education as a human right in emergencies, in the Middle East generally but specifically in Iraq. Her dissertation project is titled: Displaced Iraqis' Navigational Access to Education. 


\section{References}

Ghorashi, H. (2005). Agents of Change or Passive Victims: The Impact of Welfare States (the Case of the Netherlands) on Refugees. Journal of Refugee Studies, 18(2), 181198. https: / / doi.org/10.1093/ refuge/fei020

Parekh, S. (2020). Reframing the refugee crisis: From Rescue to Interconnection. Ethics $\mathcal{E}$ Global Politics, 13(1), 21-32. https: / / doi.org/10.1080/16544951.2020.1735013

Scheper-Hughes, N. (1995). The Primacy of the Ethical: Propositions for a Militant Anthropology. Current Anthropology, 36(3), 409-440.

Tuck, E. (2009). Suspending Damage: A Letter to Communities. Harvard Educational Review, 79(3), 409-428.

Tuck, E. \& Yang, K. W. (2012). Decolonization is not a Metaphor. Decolonization: Indigeneity, education $\mathcal{E}$ society, 1(1), 1-40.

University of Oxford. (2021). Student numbers. https:/ / www.ox.ac.uk/about/facts-andfigures / student-numbers 